\title{
The Hepatoprotective Effect of Ethanol Extract of Syzygium campanulatum (Korth) and Syzygium aromaticum (L) Leaf on Male Wistar Rat (Rattus Norvegicus) was Induced by Paracetamol
}

\author{
(Efek Hepatoprotektor Ekstrak Etanol Daun Pucuk Merah \\ (Syzygium campanulatum (Korth) dan Daun Cengkeh (Syzygium \\ aromaticum (L.) Merr. \& L. M. Perry) pada Tikus Jantan Galur \\ Wistar (Rattus norvegicus) yang diinduksi Paracetamol)
}

\author{
MUCH ILHAM NOVALISA AJI WIBOWO*, NUR AENI, ZIDNA MAZAYATUL HUDA, \\ NUNUK ARIES NURULITA
}

Fakultas Farmasi Universitas Muhammadiyah Purwokerto

Diterima, 16 Maret 2017, Disetujui 8 Juli 2017

\begin{abstract}
Abstrak: Daun cengkeh dan daun pucuk merah mengandung komponen antioksidan seperti flavonoid, fenolik, dan terpenoid sehingga diduga memiliki efek hepatoprotektor dalam mengurangi SGPT dan SGOT. Penelitian ini bertujuan untuk mengetahui efek hepatoprotektor dan menentukan potensi hepatoprotektif dari ekstrak etanol daun pucuk merah dan daun cengkeh yang dibandingkan dengan tablet Curcuma. Penelitian ini menggunakan tikus jantan galur wistar yang dibagi menjadi 6 kelompok. Kelompok I, II, III (sebagai kontrol normal, kontrol induksi, dan kontrol pembanding), kelompok IV, V, VI diberi ekstrak uji dengan dosis 105, 210, dan $420 \mathrm{mg} / \mathrm{kg}$ BB. Penelitian dilakukan selama 9 hari. Setelah 7 hari diberi perlakuan, semua kelompok diberi parasetamol dosis hepatotoksik kecuali kelompok kontrol normal. Setelah 48 jam diinduksi oleh parasetamol, dilakukan pengukuran SGPT dan SGOT terhadap semua kelompok. Hasil penelitian dapat disimpulkan bahwa ekstrak daun pucuk merah mempunyai aktivitas sebagai hepatoprotektor pada dosis $210 \mathrm{mg} / \mathrm{kg}$ BB yang sebanding dengan tablet curcuma (SGPT 21,76 $\pm 3,98 \mathrm{U} / \mathrm{L}$ dan SGOT 7,32 $\pm 6,74 \mathrm{U} / \mathrm{L}$ ) dan pada dosis $420 \mathrm{mg} / \mathrm{kg}$ BB ekstrak daun pucuk merah memiliki aktivitas hepatoprotektor yang lebih baik dari tablet curcuma (SGPT 12,43 $\pm 6,51$ U/L dan SGOT 6,64 $\pm 5,88 \mathrm{U} / \mathrm{L}$ ). Sedangkan ekstrak etanol daun cengkeh mempunyai aktivitas hepatoprotektor yang sebanding dengan tablet curcuma pada dosis 105, 210, dan $420 \mathrm{mg} / \mathrm{kgBB}$.
\end{abstract}

Kata Kunci: Hepatoprotektor, Syzygium campanulatum, Syzygium aromaticum, SGPT, SGOT.

\begin{abstract}
Syzygium campanulatum and Syzygium aromaticum contains antioxidant components such as flavonoids, phenolic, and terpenoids. May have hepatoprotective properties in reducing SGPT and SGOT activity. This research wants to determine the potency of hepatoprotective of ethanolic extract of Syzygium campanulatum (Korth) and Syzygium aromaticum leaf compared with curcuma tablets. This research uses 24 male Wistar rats divided into 6 groups: I, II, III (as a normal, induction, and compared control), group IV, V, VI were treated 105, 210 , and $420 \mathrm{mg} / \mathrm{kg} \mathrm{BW}$ respectively. The study was conducted for 9 days. After 7 days of treatment, treated groups were exposed by hepatotoxic dose of paracetamol $(2000 \mathrm{mg} / \mathrm{kg} \mathrm{BW})$. The SGPT and SGOT activity of all groups was measured by enzimatic assay. The result can be concluded that Syzygium campanulatum extract was found to be active as hepatoprotective agent with $210 \mathrm{mg} / \mathrm{kg}$ BW dosage (SGPT $21.76 \pm 3.98 \mathrm{U} / \mathrm{L}$ and SGOT 7.32 \pm 6.74 $\mathrm{U} / \mathrm{L}$ ) as effective as with the curcuma tablets (SGPT $23.91 \pm 4.41 \mathrm{U} / \mathrm{L}$ and SGOT 14.12 $\pm 5.37 \mathrm{U} / \mathrm{L}$ ) and the hepatoprotective activity of Syzygium campanulatum extract at a dosage $420 \mathrm{mg} / \mathrm{kg}$ BW better than curcuma tablets (SGPT $12.43 \pm 6.51 \mathrm{U} / \mathrm{L}$ and SGOT $6.64 \pm 5.88 \mathrm{U} / \mathrm{L}$ ). While the hepatoprotective activity of Syzygium aromaticum extracts effective as with curcuma tablets at all dosage variation.
\end{abstract}

Keywords: Hepatoprotector, Syzygium campanulatum, Syzygium aromaticum, SGPT, SGOT.

\footnotetext{
* Penulis korespondensi, Hp. 081227808091

e-mail: aji.wibowo.ump@gmail.com
} 


\section{PENDAHULUAN}

HATI merupakan organ penting bagi tubuh dan merupakan pusat metabolisme tubuh dengan fungsi yang sangat kompleks. Hati sangat berpotensial mengalami kerusakan karena merupakan organ pertama setelah saluran pencernaan yang terpapar oleh bahan-bahan yang bersifat toksik. Proses metabolisme hati akan mendetoksifikasi bahan-bahan toksik, tetapi proses ini dapat menghasilkan metabolit yang bersifat lebih toksik ${ }^{(1)}$.

Kerusakan hati dapat disebabkan oleh beberapa hal, tidak hanya disebabkan oleh infeksi dan virus saja. Hati juga dapat mengalami kerusakan akibat senyawa toksik. Kerusakan hepar karena zat toksik dipengaruhi oleh beberapa faktor seperti jenis zat kimia yang terlibat, dosis obat yang diberikan, dan lamannya paparan zat tersebut. Hati akan mengalami kerusakan akibat paparan zat toksik yang berlebihan. Selain terpapar zat toksik, pola hidup yang tidak sehat seperti konsumsi makanan yang mengandung minyak goreng berlebihan, serta konsumsi alkohol juga dapat menyebabkan kerusakan sel hati( ${ }^{(2)}$. Salah satu tanda adanya kerusakan pada hati adalah meningkatnya aktivitas Serum Glutamic Oxaloacetic Transaminase (SGOT) dan Serum Glutamic Pyruvic Transaminase (SGPT) $^{(3)}$

Antioksidan merupakan zat yang dapat melindungi kerusakan sel hati. Hal ini dibuktikan pada penelitian sebelumnya oleh Wijayanti (2008) $)^{(4)}$ bahwa kandungan antioksidan yang terdiri dari flavonoid, tannin, triterpene, saponin, dan polifenol pada daun salam telah terbukti memiliki aktivitas hepatoprotektor dengan mekanisme menghambat peroksidasi lipid yang ditimbulkan akibat paparan $\mathrm{CCl}_{4}$.

Daun pucuk merah mengandung flavonoid asam batulinat dan terpenoid berupa Dimethyl chalcone, yang diketahui memiliki aktivitas antiinflamasi dan antioksidan. Penelitian Yu $(2011)^{(5)}$ dan Yi $(2014)^{(6)}$ membuktikan bahwa asam batulinat dan dimethyl chalcone dapat mencegah kerusakan sel hati tikus akibat paparan paracetamol dan zat toksik berupa karbon tetraklorida.

Cengkeh mengandung beberapa komponen fenol, yaitu eugenol $\left(\mathrm{C}_{18} \mathrm{H}_{12} \mathrm{O}_{3}\right)$, asetil eugenol, $\alpha$ dan $\beta$ kariofelin, eugenia (isomer eugenol), vanilin, dan asam galotanin yang memiliki aktivitas antioksidan. Menurut Mu'nisa et al (2012) ${ }^{(7)}$ eugenol memiliki efek yangsama dengan $\alpha$-tokoferol dalam menghambat lipid peroksidasi, oksidasi LDL, dan lipoprotein berkepadatan rendah (VLDL).

Berdasarkan penelitian-penelitian tersebut maka pada penelitian ini akan dilakukan pengujian terhadap ekstrak etanol daun pucuk merah dan daun cengkeh yang diduga memiliki aktivitas hepatoprotektor, menggunakan hewan uji tikus jantan galur wistar yang diinduksi dengan paracetamol sebagai model toksikan yang merusak sel-sel hati hewan percobaan. Dengan parameter yang digunakan yaitu aktivitas serum transminase SGOT dan SGPT.

\section{METODE PENELITIAN}

Rancangan Penelitian. Penelitian ini menggunakan metode eksperimental dengan rancangan Post Test Only Controlled Group Design. Subjek dibagi dalam 6 kelompok dimana setiap kelompok terdapat 4 hewan uji dan dibedakan berdasakan perlakuan yang diberikan yaitu kelompok normal (Na CMC 1\%), kelompok kontrol induksi (paracetamol $2000 \mathrm{mg} / \mathrm{kg} \mathrm{BB})^{(8)}$, kelompok kontrol pembanding (curcuma $200 \mathrm{mg} / \mathrm{kg} \mathrm{BB}$ ), kelompok kontrol perlakuan 1 (diberikan ekstrak etanol daun pucuk merah dan daun cengkeh $105 \mathrm{mg} / \mathrm{kg}$ BB dan paracetamol $2000 \mathrm{mg} / \mathrm{kg} \mathrm{BB}$ ), kelompok kontrol perlakuan 2 (diberikan ekstrak etanol daun pucuk merah dan daun cengkeh $210 \mathrm{mg} / \mathrm{kg} \mathrm{BB}$ dan paracetamol $2000 \mathrm{mg} / \mathrm{kg} \mathrm{BB}$ ) dan kelompok perlakuan 3 (diberikan ekstrak etanol dan daun pucuk merah dan daun cengkeh $420 \mathrm{mg} / \mathrm{kg}$ BB dan paracetamol $2000 \mathrm{mg} / \mathrm{kg} \mathrm{BB}$ ). Kelompok perlakuan 1 sampai 3 diberikan ekstrak terpisah dengan dosis ekstrak yang berbeda. Parameter yang digunakan dalam uji efek hepatoprotektor pada penelitian ini adalah aktivitas SGPT dan SGOT. Dalam penelitian ini diharapkan ekstrak etanol daun pucuk merah mampu menurunkan aktivitas SGOT dan SGPT sesuai aktivitas normal.

BAHAN. Bahan-bahan yang diperlukan untuk penelitian ini meliputi tikus putih (Rattus norvegicus L.) jantan galur wistar umur 2-3 bulan dengan berat badan 200-250 g sebanyak 20 tikus, uji yang digunakan dalam penelitian ini adalah paracetamol, etanol $96 \%$, makanan hewan percobaan (pellet dan air), reagen Kit SGOT dan SGPT Elitech ${ }^{\circledR}$ yang terdiri dari: Reagen SGPT (reagen I) Tris, L-alanin, laktat dehidrogenase, Reagen SGPT (reagen II) 2-oksoglutarat, NADH. Reagen SGOT (reagen I) Tris, L-aspartat, malat dehidrogenase, laktat dehidrogenase, reagen SGOT (reagen II) 2-oksoglutarat, NADH.

ALAT. Alat yang digunakan untuk melakukan uji efek hepatoprotektor daun pucuk merah adalah kandang tikus 5 buah masing-masing untuk 5 ekor tikus, timbangan hewan dan timbangan neraca, sonde lambung, mikro pipet, pengaduk kaca, alatalat gelas, tabung reaksi, cawan penguap, kertas saring, alumunium foil, waterbath, spuit injeksi, 
spektrofotometer UV-Vis, rotary vakum evaporator, chamber KLT, dan sendok sungu.

Ekstraksi Daun Pucuk Merah. Pembuatan ekstrak etanol daun pucuk merah dimulai dengan mengambil bagian daun yang hijau kemudian daun yang diperoleh dicuci dengan air mengalir. Selanjutnya dikeringkan menggunakan selama 3 hari pada suhu $45{ }^{\circ} \mathrm{C}$. Untuk mendapatkan ekstrak etanol diperoleh dengan cara mengambil $500 \mathrm{~g}$ bubuk daun pucuk merah yang telah dikeringkan kemudian diekstrasi dengan metode maserasi menggunakan $3000 \mathrm{ml}$ etanol 96\% (1000 mL untuk maserasi dan $2000 \mathrm{ml}$ untuk remaserasi). Kemudian filtrat yang diperoleh disaring dan diuapkan menggunakan rotary evaporator pada suhu $40^{\circ} \mathrm{C}$. Setelah diuapkan filtrat yang diperoleh diletakkan pada cawan porselen untuk selanjutnya dilakukan penguapan diatas waterbath hinggadiperoleh ekstrak kental ${ }^{(9)}$.

Ekstraksi Daun Cengkeh. Bahan yang digunakan dalam penelitian ini yaitu daun cengkeh yang dikeringkan. Pengeringan dilakukan dengan cara dikering anginkan selama 4 minggu, kemudian dihaluskan dan diayak menggunakan ayakan ukuran 40 mesh. Ekstrak etanol diperoleh dengan merendam $100 \mathrm{~g}$ serbuk daun cengkeh dengan pelarut etanol $80 \%$ sebanyak $500 \mathrm{~mL}$, ekstraksi dilakukan 2 kali dengan menggunakan pengaduk magnet selama 24 jam. Campuran antara serbuk dengan pelarut disaring, selanjutnya dievaporasi untuk menghilangkan pelarutnya dengan rotari evaporator pada suhu $45^{\circ} \mathrm{C}$ sehingga diperoleh ekstrak etanol daun cengkeh ${ }^{(7,10)}$.

Perlakuan Hewan Uji. Tikus jantan galur wistar (Rattus norvegicus) dengan berat badan 150-200 g diadaptasikan dengan lingkungan laboratorium selama 2 minggu dan diberi pakan standar serta diberi air minum. Kemudian sampel tikus dibagi secara acak menjadi 6 kelompok masing-masing 4 hewan uji. Setelah diadaptasikan, tikus diberi perlakuan selama 7 hari. Setelah kelompok perlakuan diberi ekstrak etanol, 2 jam setelah pemberian perlakuan semua kelompok perlakuan diberi paracetamol dosis toksik yaitu $2000 \mathrm{mg} / \mathrm{kg}$ BB. Pemberian perlakuan dilakukan secara peroral. Kemudian 48 jam setelah kelompok perlakuan diberi paracetamol dosis toksik, tiap-tiap subjek penelitian diambil darahnya sebanyak $2 \mathrm{~mL}$ melalui vena lateralis untuk selanjutnya dilakukan pengukuran aktivitas enzim SGOT dan SGPT. Penelitian ini sudah mendapatkan persetujuan etik dari komisi etik Komisi Etik Penelitian Kesehatan Fakultas Kedokteran Universitas Jenderal Soedirman.

Uji Efek Hepatoprotektor. Penetapan aktivitas SGOT dan SGPT diawali dengan pengambilan darah melalui pembuluh vena pada ekor tikus sebanyak 2 $\mathrm{ml}$, didiamkan \pm 20 menit dan disentrifuge dengan kecepatan $2500 \mathrm{rpm}$ selama 15 menit hingga didapatkan serum. Setelah itu dibaca aktivitas SGOT dan SGPT menggunakan alat spektrofotometer. Aktivitas SGOT dan SGPT ditetapkan berdasarkan reaksi enzimatik. Serum diambil sebanyak $200 \mu \mathrm{L}$ dan dicampurkan dengan reagent kit sebanyak 1000 $\mu \mathrm{L}$ pada suhu pencampuran $25{ }^{\circ} \mathrm{C} / 30{ }^{\circ} \mathrm{C}$. Setelah homogen dibaca absorbansinya pada menit 1,2 , dan 3 menggunakan spektrofotometer dengan panjang gelombang $340 \mathrm{~nm}$. Data yang didapatkan berupa $\triangle \mathrm{A}$ sehingga untuk mendapatkan aktivitas SGOT dan SGPT adalah:

Activity SGOT $(\mathrm{U} / \mathrm{L})=\Delta \mathrm{A} / \mathrm{min} . \mathrm{x} 1746$

Activity SGPT $(\mathrm{U} / \mathrm{L})=\Delta \mathrm{A} / \mathrm{min} . \mathrm{x} 1745$

Identifikasi Senyawa Metode KLT. Pada identifikasi senyawa aktif golongan terpenoid dilakukan dengan cara bejana kromatografi dijenuhkan terlebih dahulu dengan fase gerak toluen:etil asetat (7:3). Ekstrak etanol daun cengkeh ditotolkan pada lempeng KLT silica gel $F_{254}$ p.a, kemudian dielusi dengan fase gerak. Selanjutnya lempeng KLT diambil, dikeringkan, diamati pada sinar $\mathrm{UV}_{365}$ dan $\mathrm{UV}_{254}$, serta visibel. Bercak dideteksi dengan penampak bercak vanillin-asam sulfat. Dari bercak yang terdeteksi, selanjutnya dilakukan perhitungan nilai retardation factor (Rf).

Cara yang sama dilakukan pada identifikasi flavonoid dan alkaloid. Fase gerak yang digunakan untuk identifikasi flavonoid berupa n-butanol : asam asetat : air (4:1:5) dengan penampak bercak reagen $\mathrm{AlCl}_{3}$. Sedangkan untuk identifikasi alkaloid fase gerak yang digunakan adalah metanol : amoniak (100 :1:5) dengan penampak bercak pereaksi dragendorf ${ }^{(11)}$.

Analisis Data. Data aktivitas SGPT dan SGOT yang diperoleh dari tiap perlakuan dianalisa secara statistika dengan progam komputer SPSS menggunakan uji nonparametrik Kruskal-Wallis untuk melihat perbedaan dalam seluruh kelompok. Kemudian dilanjutkan dengan uji Mann-Whitney untuk melihat letak perbedaan antara kelompok yang satu dengan kelompok lainnya ${ }^{(12)}$.

\section{HASIL DAN PEMBAHASAN}

Ekstraksi daun pucuk merah dan daun cengkeh. Setelah daun pucuk merah dan daun cengkeh diekstraksi, diperoleh ekstrak kental daun cengkeh sebesar 53,02 g dan rendemen ekstrak sebesar 13,2\%. Sedangkan pada daun pucuk merah diperoleh ekstrak kental sebanyak 59,55 g dan rendemen ekstrak yang 
diperoleh sebesar $11,91 \%$.

Uji Efek Hepatoprotektor. Uji efek hepatoprotektor terhadap ekstrak etanol daun pucuk merah dan daun cengkeh dilakukan dengan cara mengukur salah satu parameter uji biokimia fungsi hati yaitu aktivitas enzim transminase yaitu SGPT dan SGOT. Pengukuruan aktivitas enzim SGPT dan SGOT dilakukan 1 kali setelah perlakuan (post test) yaitu pada hari ke-7 setelah perlakuan.
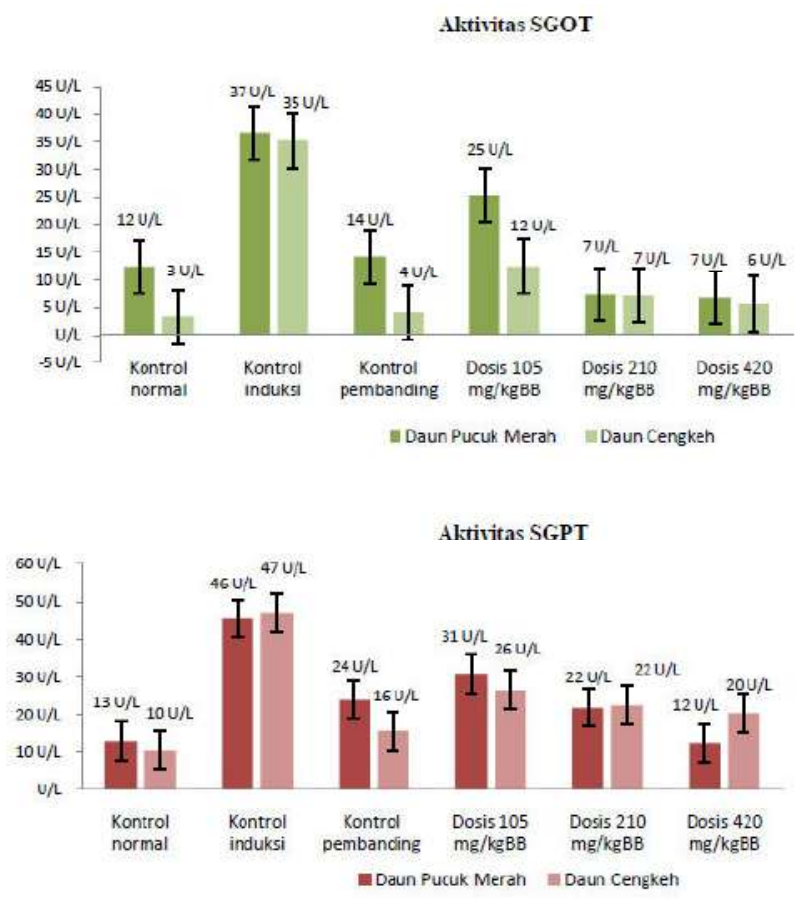

Gambar 1. Aktivitas SGPT dan SGOT Hewan Uji Setelah Pemberian Ekstrak Etanol Daun Pucuk Merah dan Daun Cengkeh.

Induksi paracetamol sebesar $2000 \mathrm{mg} / \mathrm{kgBB}$ menyebabkan adanya peningkatan aktivitas SGPT dan SGOT (Gambar 1). Proses hepatotoksik parasetamol dikarenakan adanya pembentukan metabolit saat reaksi dengan sitokrom P450.Parasetamol dalam dosis toksik dapat menyebabkan kejenuhan jalur sulfasi dan glukoronidasi, sehingga terbentuk produk toksik yang dihasilkan selama metabolisme xenobiotik parasetamol (NAPQI) dalam jumlah besar sehingga mengakibatkan deplesi GSH. NAPQI akan bereaksi dengan makromolekul sehingga menyebabkan kerusakan dan kematian sel di hepar ${ }^{(3)}$.

Semua kelompok perlakuan baik ekstrak etanol daun pucuk merah maupun daun cengkeh mengalami penurunan aktivitas SGPT dan SGOT bila dibandingkan dengan kontrol induksinya. Hal ini menegaskan bahwa ekstrak etanol daun pucuk merah dan daun cengkeh memiliki efek hepatoprotektor terhadap tikus yang terpapar paracetamol. Penurunan aktivitas enzim SGPT dan SGOT juga terjadi pada kontrol pembanding yaitu Curcuma $200 \mathrm{mg} / \mathrm{kgBB}$ (tabel 1).

Tabel 1. Aktivitas SGOT dan SGPT Setelah Pemberian Ekstrak Etanol Daun Pucuk Merah dan Daun Cengkeh Berdasarkan Uji Statistik Kruskall-Wallis.

\begin{tabular}{|c|c|c|c|c|}
\hline \multirow[t]{5}{*}{ Kelompols } & \multicolumn{4}{|c|}{ Ekstrak Etanol } \\
\hline & \multicolumn{2}{|c|}{ Daun Pucuk Merah } & \multicolumn{2}{|c|}{ Daun Cengkeh } \\
\hline & Rerata Aktivitas & Rerata Aktivitas & Rerata Aktivitas & Rerata Alktivitas \\
\hline & $S G P T=S D$ & $\mathrm{SGOT}=\mathrm{SD}$ & $S G P T=S D$ & SGOT $\pm S D$ \\
\hline & $(\mathrm{U} / \mathrm{L})$ & $(\mathrm{UL})$ & (U/L) & (UL) \\
\hline Kontrol normal & $13.01=6.96$ & $12.38 \pm 5.05$ & $10.39 \pm 2.97$ & $3.24 \pm 2.73$ \\
\hline Kontrol induksi & $45.53=1.24$ & $36.71=5.22$ & $46.90=7.20$ & $35.23 \pm 1.00$ \\
\hline Kontrol pembanding & g $23.91 \pm 4.41$ & $14.12=5.37$ & $15.60=5.00$ & $4.07 \pm 2.43$ \\
\hline Dosis $105 \mathrm{mg} / \mathrm{kg} \mathrm{BB}$ & B $30.84 \pm 3.58$ & $25.30=3.37$ & $26.46 \pm 1.43$ & $12.41=1.56$ \\
\hline Dosis $210 \mathrm{mg} / \mathrm{kg} B B$ & B. $21.76 \pm 3.98$ & $7.32 \pm 6.74^{*}$ & $22.35 \pm 1.26$ & $7.06 \pm 2.06$ \\
\hline Dosis $420 \mathrm{mg} / \mathrm{kg}$ BB & $12.43 \pm 6.51^{*}$ & $6.64 \pm 5.88^{*}$ & $20.33 \pm 7.95$ & $5.58 \pm 1.60$ \\
\hline
\end{tabular}

Keterangan: Berbeda bermakna dengan kontrol pembanding $(\mathrm{P}<0,05)$.

Berdasarkan analisis Kruskal Wallis (Gambar 1), adanya perbedaan perlakuan terhadap hewan uji pada masing-masing kelompok menyebabkan perbedaan peningkatan aktivitas SGPT dan SGOT $(p<0,05)$ dimana setiap kelompok terdapat 4 hewan uji. Sehingga untuk mengetahui kelompok mana saja yang memiliki perbedaan bermakna maka dilakukan analisa Post Hoc dengan uji Mann Whitney.

Bila dibandingkan dengan kontrol pembandingnya, pemberian ekstrak etanol daun cengkeh pada semua variasi dosis tidak memberikan perbedaan yang bermakna ( $p>0,05)$ pada aktivitas SGPT maupun SGOT. Hal ini menunjukkan bahwa pemberian ekstrak etanol daun cengkeh memiliki aktivitas hepatoprotektor yang sebanding dengan tablet curcuma $200 \mathrm{mg} / \mathrm{kg} \mathrm{BB}$.

Berbeda dengan ektrak etanol daun cengkeh, pemberian ekstrak etanol daun pucuk merah pada dosis $105 \mathrm{mg} / \mathrm{kg}$ BB memberikan perbedaan yang bermakna $(\mathrm{p}<0,05)$ pada aktivitas SGPT dan SGOT jika dibandingkan dengan kontrol normalnya. Hal ini menegaskan bahwa pada dosis $105 \mathrm{mg} / \mathrm{kg} \mathrm{BB}$ ekstrak etanol daun pucuk merah belum dapat memberikan efek hepatoprotektor karena tidak dapat menurunkan aktivitas SGPT dan SGOT secara signifikan. Apabila dibandingkan dengan kontrol pembandingnya, ekstrak etanol daun pucuk merah pada dosis 210 $\mathrm{mg} / \mathrm{kg} \mathrm{BB}$ justru tidak menunjukkan perbedaan yang bermakna $(\mathrm{p}>0,05)$ pada aktivitas SGPT, tetapi terdapat perbedaan bermakna $(\mathrm{p}<0,05)$ pada aktivitas 
SGOT. Dapat disimpulkan bahwa pada dosis $210 \mathrm{mg} /$ kg BB ekstrak etanol daun pucuk merah memiliki efek hepatoprotektor yang sebanding dengan tablet curcuma dalam menurunkan SGPT. Sedangkan ekstrak etanol daun pucuk merah pada dosis $420 \mathrm{mg}$ / kg BB memiliki perbedaan bermakna $(\mathrm{p}<0.05)$ apabila dibandingkan dengan kontrol pembandingnya, baik dalam menurunkan kadar SGPT maupun SGOT. Hal ini membuktikan bahwa ekstrak etanol daun pucuk merah pada dosis $420 \mathrm{mg} / \mathrm{kg}$ BB memiliki efek hepatoprotektor yang lebih baik jika dibandingkan tablet curcuma.

Identifikasi Senyawa Metode KLT. Identifikasi Terpenoid. Pada kromatogram hasil identifikasi terpenoid terhadap ekstrak etanol daun cengkeh menghasilkan bercak meredam ber warna biru pada $\mathrm{UV}_{254 \mathrm{~nm}}$, sedangkan pada $\mathrm{UV}_{365 \mathrm{~nm}}$ terlihat bercak meredam kuning. Pengamatan bercak dibawah sinar tampak menghasilkan bercak berwarna merah violet. Bercak senyawa terpenoid pada ekstrak etanol daun cengkeh terdeteksi pada Rf yaitu 0,42. Sedangkan pada daun pucuk merah menghasilkan bercak meredam berwarna biru muda, violet dan kuning pada $\mathrm{UV}_{366}$. Kemudian pengamatan bercak dibawah sinar tampak menghasilkan lebih dari satu bercak berwarna violet setelah disemprot dengan pereaksi vanilin-asam sulfat. Hal ini menunjukkan dalam ekstrak etanol daun cengkeh dan daun pucuk merah memiliki kandungan terpenoid dengan konsentrasi yang berbeda-beda.

Identifikasi Alkaloid. Pada kromatogram hasil identifikasi alkaloid, setelah dilakukan penyemprotan dengan pereaksi dragendorff, tidak terlihat adanya bercak senyawa alkaloid dibawah sinar $\mathrm{UV}_{366 \mathrm{~nm}}$ yang menegaskan bahwa tidak ada kandungan alkaloid dalam ekstrak etanol daun pucuk merah dan daun cengkeh.

Identifikasi Flavonoid. Pada kromatogram hasil identifikasi flavoinoid terhadap ekstrak etanol daun cengkeh dan daun pucuk merah timbul noda yang berwarna kuning setelah disemprot dengan pereaksi $\mathrm{AlCl}_{3} 5 \%$ pada pengamatan sinar tampak. Pada pengamatan dengan sinar $\mathrm{UV}_{366}$ hanya menunjukkan noda berwarna kuning pada ekstrak etanol daun cengkeh sedangkan pada ekstrak etanol daun pucuk merah noda berwarna kuning dan biru. Noda tersebut menegaskan adanya kandungan flavonoid pada ekstrak etanol daun pucuk merah dan daun cengkeh. Hasil identifikasi kandungan senyawa terhadap ekstrak etanol daun pucuk merah dan daun cengkeh dapat dilihat pada tabel 2 .
Tabel 2. Rangkuman Hasil Identifikasi Kandungan Senyawa terhadap Ekstrak Etanol Daun Pucuk Merah dan Daun Cengkeh Menggunakan Metode KLT.

\begin{tabular}{|c|c|c|c|c|c|}
\hline \multirow{2}{*}{$\begin{array}{c}\text { Ekstrak } \\
\text { Etanol }\end{array}$} & \multirow{2}{*}{$\begin{array}{c}\text { Identifikasi } \\
\text { KLI }\end{array}$} & \multirow{2}{*}{ Pereaksi } & \multicolumn{3}{|c|}{ Hasil } \\
\hline & & & Visible & UV $366 \mathrm{~nm}$ & Ket. \\
\hline & Flavonoid & $\mathrm{AlCl}_{3}$ & Kuning & $\begin{array}{l}\text { Biru muda } \\
\text { Kuning }\end{array}$ & Positif \\
\hline $\begin{array}{l}\text { Daun Pucuk } \\
\text { Merah }\end{array}$ & Terpenoid & $\begin{array}{c}\text { Vanilin-asam } \\
\text { sulfat }\end{array}$ & Violet & $\begin{array}{l}\text { Biru muda } \\
\text { Kuning } \\
\text { Violet }\end{array}$ & Positif \\
\hline \multirow{3}{*}{$\begin{array}{l}\text { Daun } \\
\text { Cengkeh }\end{array}$} & $\begin{array}{l}\text { Alkaloid } \\
\text { Flavonoid }\end{array}$ & $\begin{array}{c}\text { Dragendorf } \\
\mathrm{AlCl}_{3}\end{array}$ & Kuning & kuing & $\begin{array}{l}\text { Negatif } \\
\text { Positif }\end{array}$ \\
\hline & Terpenoid & $\begin{array}{l}\text { Vanilin-sasam } \\
\text { sulfat }\end{array}$ & Violet & kuing & Positif \\
\hline & Alkaloid & Dragendorf & - & - & Negatif \\
\hline
\end{tabular}

Pada penelitian ini daun pucuk merah dan daun cengkeh telah terbukti memiliki metabolit sekunder berupa terpenoid dan flavonoid. Flavonoid bersifat antioksidan karena memiliki gugus hidroksi fenolik dalam struktur molekulnya yang memiliki daya tangkap radikal bebas. Gugus $\mathrm{OH}$ pada senyawa flavonoid akan menggantikan glutation (GSH) yang telah terdeplesi oleh radikal bebas akibat pemberian parasetamol dosis toksik. Melalui mekanisme inilah Gugus $\mathrm{OH}$ pada flavonoid akan membantu konjugasi parasetamol menjadi asam merkapturat (bentuk non toksik) dan mengubah metabolit reaktif parasetamol hasil metabolisme sitokrom P-450 yaitu $N$-acetyl p-benzoquinon-imine (NAPQI) menjadi metabolit non-aktif yang bersifat hidrofilik sehingga mudah dieksresikan melalui urin. Melalui mekanisme ini secara tidak langsung metabolit reaktif parasetamol yaitu NAPQI dapat direduksi dan efek hepatoprotektor dapat terwujud ${ }^{(3)}$. Potensi flavonoid sebagai hepatoprotektor ini juga telah dibuktikan pada penelitian sebelumnya yang menyatakan bahwa flavonoid yang terdapat pada biji alpukat dapat menghambat terjadinya ikatan antara senyawa radikal peroksi dengan asam lemak yang terdapat di hati yang menyebabkan terjadinya peroksidasi lipid. Dengan demikian reaksi steatosis bisa diminimalisasi atau bahkan dihentikan.

Menurut penelitian Mu'nisa et al (2012) (7) dan Lumingkewas et al (2014) ${ }^{(10)}$ daun cengkeh memiliki aktivitas antioksidan yang dapat menghambat efek toksik paracetamol melalui pengikatan radikal bebas dan dekomposisi peroksida lipid. Kemudian menurut Ogata et al (2000) $)^{(13)}$, cengkeh mengandung beberapa komponen fenol, yaitu eugenol $\left(\mathrm{C}_{18} \mathrm{H}_{12} \mathrm{O}_{3}\right)$, asetil eugenol, $\alpha$ dan $\beta$ kariofelin, eugenia (isomer eugenol), vanilin, dan asam galotanin. Eugenol memiliki aktivitas antioksidan yang efeknya sama dengan $\alpha$-tokoferol dalam menghambat lipid peroksidasi, 
oksidasi LDL, dan lipoprotein berkepadatan rendah (VLDL).

Pada penelitian sebelumnya daun pucuk merah telah diketahui memiliki beberapa komponen seperti saponin, fenolik, flavonoid, dan terpenoid. Menurut Memon (2014) beberapa senyawa aktif yang terdapat pada daun pucuk merah antara lain golongan flavonoid yaitu Dimethyl Cardamonin dan senyawa aktif golongan triterpenoid seperti asam batulinat. Senyawa-senyawa tersebut dimungkinkan memliki peranan penting dalam aktivitas hepatoprotektor. Hal ini didukung dengan penelitian yang dilakukan oleh Yu, (2011) $)^{(5)}$ yang membuktikan bahwa pemberian Dimethyl Cardamonine secara signifikan dapat menurunkan aktivitas serum transminase, laktat dehidrogenase, fosfatase alkali, $\gamma$-glutamil transferase, dan bilirubin total, serta penurunan elevasi peroksidasi lipid, malondialdehid, spesies oksigen reaktif, dan protein carbonyl conten pada tikus Kunming yang terpapar karbon tetraklorida secara akut.

Selain itu Agnieszka (2010) ${ }^{(13)}$ juga membuktikan bahwa pemberian asam batulinat dapat menurunkan anion superoksida dan hidrogen peroksida akibat toksisitas paracetamol dan produksi spesies organ reaktif dalam sel HepG2 (Human Hepatocelluler Carcinoma).

Merujuk pada penelitian-penelitian terdahulu,maka mekanisme hepatoprotektor oleh ekstrak etanol daun pucuk merah dan daun cengkeh pada penelitian ini diduga terkait dengan peningkatan kapasitas antioksidan, pemeliharaan sistem antioksidan, pelemahan stress oksidatif, dan penghambatan peroksidasi lipid.

\section{SIMPULAN}

Ekstrak etanol daun pucuk merah dan daun cengkeh memiliki efek hepatoprotektor terhadap tikus yang diinduksi paracetamol. Ekstrak etanol daun cengkeh memiliki efek hepatoprotektor yang sebanding dengan tablet curcuma. Sedangkan efek hepatoprotektor ekstrak etanol daun pucuk merah pada dosis $420 \mathrm{mg} /$ $\mathrm{kg}$ BB lebih baik dari tablet curcuma.

\section{DAFTAR PUSTAKA}

1. Tappi. et al. 2013. "Gambaran Histopatologi Hati Tikus Wistar yang Diberikan Jus Tomat (Solanum lycopersicum) Pasca Kerusakan Hati Wistar yang
Diinduksi Karbon Tetraklorida (CCl4)".Jurnal eBiomedik (eBM) 1 (3).

2. Yenny, Herwana E., Marwoto, W., Setiabudy, R.. 2011. Efek Schizandrine c terhadap kerusakan hati akibat pemberian parasetamol pada tikus. Universa Medika 24 (4) : 161-6

3. Amirudin, R., 2009. Fisiologi dan Biokimia hati : Buku Ajar Ilmu Penyakit Dalam Edisi V. Jakarta. Interna Publishing. Hal : 627.

4. Wijayanti. 2008. Efek Hepatoprotektif Ekstrak Etanol $70 \%$ Daun Salam (Syzygium polyanthum) Pada Tikus Putih jantan yang di Induksi CCl4 [skripsi]. Surakarta: Fakultas Farmasi Universitas Muhammadiyah Surakarta.

5. Yu W.G., Qian Jie., Lu Yan.Hua. 2011. "Hepatoprotective effects of 2',4'-dihydroxy6'methoxy3',5' dimethylchalcone on $\mathrm{CCl}_{4}$-induced acute liver injury in mice".Journal of Agricultural and Food Chemistry,59, (2).Availablefrom: http:// pubs.acs.org/doi/abs/10.1021/jf2042032. [Accessed: 22nd July 2016]

6. Yi, Jine. et al. 2014. Betulinic acid prevents alcoholinduced liver damage by improving theantioxidant system in mice. Journal of Veterinary Science. 15 (1), 141-8

7. Mu'nisa, A., Wresdiyati, T., Kusumorini, N., Manalu, W. 2012. Aktivitas Antioksidan Ekstrak Daun Cengkeh. Jurnal Veteriner. 13 (3). Hal 272 - 277.15 (1), 141-8

8. Nirmala,K Girija, K Lakshman, and T Divya. 2012. Hepatoprotective activity of Musa paradisiaca on experimental animal models. Asian Pac J Trop Biomed 2012 Jan; 2(1): 11-5.

9. 9. Memon, A.H. et al.2014. "Isolation, Characterzation, Crystal Structure Elucidation, and Anticancer Study of Dimethyl Cardamonin Isolated From Syzygiumcampanulatum. Published by: Hindawi Publishing Corporation.

10. Lumingkewas, M., Manarisip, J., Indriaty, F., Walangitan., A., Mandei, J., Suryanto, E. (2014). Aktivitas Antifotooksidan dan komposisi fenolik dari daun cengkeh (Eugenia aromaticum). ChemProg. 7 (2). Hal $96-104$.

11. Anas, Yance ., Niken Puspitasari., Maulita Cut Nuria. 2013. Aktivitas Stimulansia Ekstrak Etanol Bunga Dan Daun Cengkeh (syzygium aromaticum (L.) Merr.\& Perry.) pada Mencit Jantan Galur Swiss Beserta Identifikasi Golongan Senyawa Aktifnya [skripsi]. Semarang: Fakultas Farmasi Universitas Wahid Hasyim Semarang.

12. Dahlan, Sopiyudin.2011. Statistik Untuk Kedokteran dan Kesehatan Edisi 5. Jakarta, Salemba Medika.

13. Ogata M, Hoshi M, Urano S, Endo T (2000). Antioxidant activity of eugenol and related monomeric and dimeric compounds. Chem. Pharm. Bull. 48: $1467-9$ 
14. Agnieszka, S.C., Karolina, Pilipów, Martyna K.Z. 2010. Protective effect of betulin and betulinicacid on acetaminophen andethanol-induced cytotoxicity and reactiveoxygen species production in HepG2 cells. Journal of Pre- Clinical and Clinical Research.4 (2), 096-100 